\title{
Ethnic conflict in Papua New Guinea
}

\author{
Benjamin Reilly \\ Centre for Democratic Institutions, Australian National University, Canberra, ACT 0200, Australia. \\ Email: Ben.Reilly@anu.edu.au
}

\begin{abstract}
On many measures of ethno-linguistic diversity, Papua New Guinea is the most fragmented society in the world. I argue that the macro-level political effect of this diversity has been to reduce, rather than increase, the impact of ethnic conflict on the state. Outside the Bougainville conflict, and (to a lesser extent) the recent upsurge of violence in the Southern Highlands, ethnic conflicts in Papua New Guinea have not presented a threat to national government. In contrast to most other ethnically diverse societies, the most consequential impacts of ethnic conflict in Papua New Guinea are at the local level. This paper therefore examines the disparate impacts of local- and national-level forms of ethnic conflict in Papua New Guinea.
\end{abstract}

Keywords: diversity, elections, ethnic conflict, Papua New Guinea

Papua New Guinea combines two unusual features which should make it a case of special interest to scholars of ethnicity and ethnic conflict. First, it boasts one of the developing world's most impressive records of democratic longevity, with more than 40 years of continuous democratic elections, all of them characterised by high levels of participation and candidature, and numerous peaceful changes of government. Even more striking, however, is that Papua New Guinea has combined this extended record of electoral democracy with high levels of ethno-linguistic fragmentation and inter-ethnic violence. The conventional wisdom is that such a level of diversity and conflict poses significant challenges to successful nation building and governance. Some observers of Papua New Guinea politics, for example, have argued that its ethnic fragmentation represents a 'formidable and intractable' impediment to nation building (Premdas, 1989: 246). However, while having experienced a number of secessionist movements, most notably on the eastern island of Bougainville, Papua New Guinea has so far been able to maintain both its territorial unity and an impressive record of formal democracy.

This paper argues that the overall effect of ethno-linguistic diversity in Papua New Guinea has been to reduce, rather than increase, the impact of ethnic conflict on the state. The reason for this is relatively straightforward: outside the Bougainville conflict and (to a lesser extent) the recent upsurge of violence in the Southern Highlands, ethnic conflicts in Papua New Guinea have not presented a threat to national government. Most conflict in Papua New Guinea takes place at the local level. While this does not make such conflicts inherently less important, it does limit their impact on national issues. Of course, local conflicts can, if left unchecked, eventually rise to challenge the state itself - as occurred in Papua New Guinea's neighbour, the Solomon Islands, in 2001-2003 where tensions between populations of the two of the main island groups, Malaita and Guadalcanal, resulted in the capture and overthrow of the elected government. However, in large part because of the unique nature of its ethno-linguistic structure, this kind of conflict for control of the state itself has never been a serious threat in Papua New Guinea. This paper therefore examines the disparate impacts of local and national-level forms of ethnic conflict in that country.

\section{Ethnic structure and ethnic conflict in Papua New Guinea}

The state of Papua New Guinea is a colonial construct. Unlike parts of neighbouring Indone- 
sia, there was no history of state-like organisation in the country before European contact. Instead, society was made up of thousands of small, acephalous and largely independent tribal units. Such political entities as existed 'were both relatively unstable and small. Not many effective political units contained more than a few hundred people, although on occasions thousands might cooperate for a specific battle, or in trade and ceremonial exchange. Membership of even the smallest primary groups was unstable - as people married in and out, disputes arose between rival leaders, and inter-group warfare forced some members of each group to choose between the claims to their loyalties of, say, their residential or their kin group' (Parker and Wolfers, 1971: 16).

Papua New Guinea is thus in many ways a state in search of a nation. In geographic terms, it comprises roughly half of the world's second largest island, New Guinea, and about 600 smaller islands, including the far eastern island province of North Solomons, better known as Bougainville, which has a history of separatism from the rest of the country. Papua New Guinea has a complex colonial history. Until 1942, the country comprised two separate jurisdictions Papua and New Guinea - which had originally fallen under British and German rule, respectively. Before the 1930s, the populous Highlands interior of the country was essentially unknown to outsiders. After assuming responsibility for the different territories, Papua New Guinea was administered by Australia from the early years of the twentieth century until 1975, when it became independent.

On most measures of ethno-linguistic diversity, Papua New Guinea is probably the most heterogeneous country in the world. At the latest count, some 852 different languages are spoken by a population of 5.3 million people (see May, 2003a). This extreme degree of linguistic diversity translates into exceptional cultural fragmentation. As in most of Melanesia, Papua New Guinea's basic cultural unit comprises ascriptive extended family networks or 'Clans' which form the primary unit of political and social loyalty (Hogbin, 1973: 23). Stephen Levine writes that if ethnic communities are understood to be groups possessing a distinctive language, custom and memories - traits that give its members a sense of unity and cause them to distinguish themselves (and be distinguished by others) - then PNG may have more than one thousand such ethnic groups within its borders' (Levine, 1997: 479).

While distinct from the larger cultural groupings around which ethnicity is often defined in other contexts, for the purposes of this paper, an 'ethnic group' constitutes any of these larger or smaller cultural-linguistic groupings whose members tend to act collectively for political purposes. Even using Levine's relatively constrained definition of ethnicity, it is clear that the level of societal heterogeneity within Papua New Guinea is exceptionally high by comparative standards. It is also clear that there is significant internal variation within Papua New Guinea, with some regions being relatively homogenous and others, especially in the Highlands areas, being exceptionally fragmented.

Considering the lack of overt racial distinction between them, the depth of cleavages between ethnic groups in Papua New Guinea is often striking, and can be partly explained by geographic factors. Papua New Guinea has some of the world's most dramatic terrain, with a vast range of mountains and valleys running through the middle of the mainland ('the Highlands') and an extensive arc of populated volcanic islands off the coast - all of which create severe difficulties in terms of isolation, access and transport. Accordingly, 'most groups developed their own physical and cultural identity in isolation... communities living on different sides of the same highland valley sometimes speak languages as distinct from one another as Spanish is from Italian' (Souter, 1963: 49). Although few groups were entirely isolated, and many had ally groups with which they conducted trade and marriage, relations between many were characterised as much by hostility as by cooperation. Traditional contact in the Highlands, for example, often took the form of intermittent tribal warfare between clan groups (Reay, 1982). Moreover, within the main language groups themselves, there are also often deep and bitter internal divisions.

Part of the difficulty of defining what constitutes an ethnic group in Papua New Guinea is the sheer variation of its ethnic structure, which limits the ability to make generalisations. For example, in lowland areas the population of ethno-linguistic units normally ranges from a 
few hundred to several thousand, whereas in the Highlands these groups are much larger (de Lepervanche, 1973: 1065). There has been little detailed assessment of the total number of ethno-linguistic groups in Papua New Guinea, but estimates of the number of separate 'political units' (i.e. clans) range from 2000 to $18000 .^{1}$ If a larger unit of base measurement is used, such as 'tribes' (i.e. aligned or related clan groupings), then we are still dealing with an extremely fragmented society: a rough average of 2500 members per tribe against Papua New Guinea's total population of approximately five million people gives a figure of around 2000 separate tribes. Even using conservative figures, then, we are dealing with a level of fragmentation that makes diverse societies elsewhere look relatively homogeneous by comparison.

This extreme ethno-linguistic fragmentation means that Papua New Guinea also has an extremely high number of politicised ethnic identities. Both traditional social relations and modern political entrepreneurship in Papua New Guinea involve the mobilisation and manipulation of such ethnic identities - a process which, as Karl Claxton notes, is itself conflict-creating in the absence of structures able to regulate competition for power, wealth and status (Claxton, 2000: 267). For example, in the Highlands, where almost half the Papua New Guinea population lives, modernisation, land pressure and competition for resources have encouraged a 'retribalisation' of society in recent decades as group affiliation is increasingly used to determine the distribution of public goods (Strathern, 1993). As such, tribal groups are increasingly being mobilised, refashioned, or at times invented from scratch, in response to the demands of state building (see Ferguson and Whitehead, 1992). For instance, Colin Filer (2000: 167-168) reports that landholding disputes in areas as varied as Central Province and the Lihir Islands have seen some claimants invent clan identities from scratch in order to facilitate collective demands for compensation.

In contemporary Papua New Guinea, clans thus increasingly play the role of interest groups. Clans compete with each other for access to resources - not only the jobs and other benefits provided by major resource projects, but also other goods and services and, perhaps most importantly, public offices which provide an entry-point to the resources of the state itself. However, the process of these many microethnic collectives competing to secure desired outcomes for their own group members inevitably and inexorably create a massive collective action dilemma for the country as a whole. ${ }^{2}$ The combined effect of many small ethnic groups acting to secure their own interests undermines the broader interests of society. Because time horizons are short, possible productive investments are curtailed. Energies are focused on short-term wealth distribution rather than long-term wealth creation. Rent-seeking 'the socially costly pursuit of wealth transfers' (Tollison, 1997: 506) - flourishes, as each tribal group attempts to monopolise any potential public good for their own ends.

The result is that public goods are increasingly diverted towards the private enrichment of political entrepreneurs and the small ethnic interest groups they represent. Productive outcomes for society at large are overwhelmed by a collective action problem created by several thousand small ethnic collectives competing with each other for resources, prestige and public goods. ${ }^{3}$ As a consequence, local politics in much of Papua New Guinea is increasingly characterised by intense zero-sum competition for a small and dwindling reward base, and life in some parts of the country has reverted to a Hobbesian struggle for meagre resources. The fragmentation of Papua New Guinea society exacerbates this problem by creating a situation of many small clans operating effectively as interest groups, attempting to exploit any available public good for their membership.

\section{Forms of ethnic conflict}

Studying the independent impact of ethnic conflict upon state performance is no easy task. For one thing, 'ethnicity' is itself a notoriously slippery concept, widely considered to be manifested as a mixture of both primordial and constructed factors. ${ }^{4}$ In other words, it is both an ascriptive phenomena, based on sociobiological traits such as race, tribe and language - a position often characterised in the scholarly literature as 'primordialism' - as well as an 
adaptive one of more malleable or constructed identities formed as a reaction to external pressures and incentives - or, to use the academic shorthand, 'constructivism'.${ }^{5}$ In addition, ethnic politics impacts on public policy in a range of more subtle ways beyond violent conflict. For instance, in competing with each other for resources, rival communities in socially heterogeneous countries can have similar impacts to interest groups or industry lobbies in the economic realm, diverting potential public goods towards the private enrichment of their membership alone.

Despite its extraordinary social structure, ethnic identity in Papua New Guinea, as elsewhere, tends to be manifested as a mixture of primordial and constructed factors, exhibiting a combination of both basic ascriptive ties and opportunistic adaptations to contemporary events. Many analyses of ethnicity in Papua New Guinea, for example, emphasise the extent to which ethnic identities were both a salient feature of traditional society and a reaction to colonialism, modernisation and independence (Premdas, 1989: 246). Today, primordial factors remain strong at all levels of Papua New Guinea society. Political loyalties, for example, are focused primarily at the level of family, clan and regional allegiances, rather than along party or ideological lines. Block voting along ethnic lines remains a common practice, particularly in the Highlands. Ethnic identity as a political factor in Papua New Guinea tends to be played out at different levels, and may manifest itself as a salient factor, in varying strengths, at the levels of extended family, clan, tribe, region, and even along the colonial divisions of the state between Papua and New Guinea.

Despite this degree of variation, it is possible to make some limited generalised observations about ethnicity and politics in Papua New Guinea. The most important distinction is between conflicts at the national level, which potentially threaten the territorial integrity of the state (such as the decade-long Bougainville conflict); those which take place at the regional level (such as the current conflict in the Southern Highlands, or 'micronationalist' combination of cargo cults, local protest groups and regional separatists campaigns that were a feature of the pre-independence period); and those that take place exclusively at the local level (which make up the vast majority of the country's ethnic conflicts).

Each of these has different impacts. While the first category of large-scale separatist conflicts that can threaten the state are rare, their impact has been devastating. The decade-long civil war on Bougainville described below, in which a variety of rebel forces attempted to secede from the rest of the country, has been the most important of these to date. The second conflict type, major regional conflicts, also presents serious problems for the sate. Thus, the debilitating and ongoing conflict in the Southern Highlands, which forced the abandonment of the 2002 elections in much of the province, contains a number of elements in common with the Bougainville case, but without the strong separatist element. These include a variety of armed groups in conflict, the presence of large numbers of high-powered firearms, an interweaving of traditional tribal enmities with modern identities and the presence of major natural resource endowments (see Goldman, 2003). The Papua New Guinea government has declared that the Southern Highlands conflict could become 'another Bougainville', with security implications for the country as a whole. $^{6}$

The third category of conflicts in Papua New Guinea are manifested not at the national or regional ethno-nationalist level, but at the micro-level, typically in the form of violence between Papua New Guinea's myriad small, competitive ethnic groups. The nature of ethnic conflict between these groups is traditionally played out locally, often via intertribal fighting, rather than as part of an ethno-nationalist quest or a competition for regional or national hegemony. However, they are no less deadly for that. Hundreds of people are killed every year in tribal fights in Papua New Guinea (Dorney, 1990: 310). Reports have estimated that around $20 \%$ of the population is affected by ostensibly 'tribal' violence, with a marked concentration in highland regions (Clifford et al., 1984: 94-95). Guns have now supplanted more traditional weapons in such conflicts, thus raising their stakes and increasing their deadliness (Dorney, 1990: 310-311). The upsurge in 'tribal' violence across much of the Highlands over the past two decades is perhaps the best example of this kind of conflict. 


\section{Conflict and democracy}

The imposition of representative democracy has also played a role in formenting such conflicts. Since independence, highly competitive elections have become an increasingly important avenue for access to the resources of the state. Electoral politics is thus a high-stakes game in which candidates and their clan supporters vie for an entry to the state which allows them to access, control and distribute public goods. In the Highlands province of Simbu, for example, 'people have come to regard government as the major, or only, source of opportunity and finance. Having a friend in national government is seen as necessary for economic success, and election to office in the provincial assembly and parliament is keenly contested' (Brown, 1989: 245). Aspiring candidates make (often optimistic) calculations of their electoral prospects based on the number of voters in their own clan and tribal support groups. Once elected, the expectation is that successful candidates will use their position to extract resources from the government and deliver them back to their own clan, but not necessarily to the electorate as a whole. Reviewing the situation in the early 1990s, Strathern (1993: 48) found that 'it was understood that politicians are in power to benefit themselves and their factions, and they concentrate on consolidating their existing power bases. As a result of armed conflict between groups, these bases had become more, rather than less, rigidly defined and a process of neotribalization was well under way'.

As the stakes for victory are so high, elections typically have the effect of sharpening ethnic cleavages, because the salience of ethnicity in Papua New Guinea 'tends to come to the fore...during national election campaigns' (Howard, 1989: 45). It is thus perhaps not surprising that studies have found a marked increase in ethnic violence at election time. Elections have today become one of the primary ways in which traditional enmities are mobilised in contemporary Papua New Guinea, even though in most cases contestation is very much for election to office itself, rather than larger concerns such as policy implementation, government formation or national ideology (Dinnen, 1996; Standish, 1996). The 2002 elections, widely criticised as the worst ever held in Papua New Guinea, featured numerous instances of bribery, intimidation and other electoral offences, including multiple voting, hijacking of ballot boxes and, in the Southern Highlands particularly, large-scale electoral violence (May, 2003b).

While a cause of great concern, this type of 'gunpoint democracy' is not, however, a dominant pattern across Papua New Guinea as a whole - at least, not yet. Indeed, there are clear regional and structural trends to election violence in Papua New Guinea: it is precisely those Highlands regions such as Enga, Simbu and the Southern and Eastern Highlands provinces where traditional clan rivalries were fiercest, and where ethnic fragmentation is most pronounced, that electoral violence today is also a major factor. Ominously, however, urban areas such as Papua New Guinea's main city, Port Moresby, are increasingly replicating these forms of negative social capital in an urban environment, via raskol criminal gangs and other collectivities formed along ethnic and cultural lines.

The Papua New Guinea experience also shows how the design of political institutions such as electoral systems can have an impact on the incidence and expression of ethnic conflict. Papua New Guinea has utilised two different electoral systems - the alternative vote (AV) and a simple plurality system. The AV requires voters to rank-order candidates in order to arrive at a majority winner, rather than just voting for a single choice. Because of the nature of Papua New Guinea society, elections held under this system enabled voters to give their first preference to their own clan or 'home' candidate. But, in many seats, this was not enough for any single candidate to gain a majority of votes; they needed the second preferences of other groups as well. In order to do this, candidates had to sell themselves as a good 'second-best' choice to other clan groups - which meant, in general, someone who would be attentive to the interests of all groups, not just their own. It also meant that those candidates who formed alliances and cooperated with each other would often be more successful than candidates who attempted to win the seat from their own voter base alone. This gave many candidates an incentive to act in an accommodative manner to other clans. The mechanics of the system also ensured that the 
winning candidate would have the support of an absolute majority of voters. In a substantial number of cases, the winning candidate was not the one who had the biggest 'bloc' of supporters, but rather the one who could successfully build support across several groups (Reilly, 2002).

After using AV for its three pre-independence elections, Papua New Guinea changed to a plurality system at independence in 1975. However, the different incentives provided by this new 'first-past-the-post' contest led to quite different outcomes than those expected. Because candidates no longer needed an absolute majority of votes cast in order to be successful, but just more than any other group, the candidate from the largest clan would often win the seat outright. There was no incentive to cooperate with anyone else. Electoral violence increased, because it was in some candidates' interests to stop opponents' supporters from voting, rather than to campaign for their second preferences as had been the case in the past. Also, because so many clans were vying to have their own candidates win a seat, candidates learned that they could be successful with very limited support. In an electoral cycle increasingly dominated by concerns about corruption, power and money politics, a range of negative tactics, such as encouraging rival candidates to stand in order to 'split' a dominant clan's voter base, became the norm. At the 2002 elections, over half the Papua New Guinea parliament was elected with less than $20 \%$ of the votes several winning candidates gained only $5 \%$. This led to growing pressure for the reintroduction of AV both internally and from external commentators.

In 2003, the Papua New Guinea parliament re-adopted a form of $\mathrm{AV}$, with preferences limited to three - known as 'limited preferential voting' - for future elections. As well as ensuring that winning candidates would have to gain a greater share of votes to get elected, it was hoped that this new electoral system would reduce electoral violence and encourage candidates to cooperate with each other during election campaigns, features distinctly absent under plurality elections. At the first use of the system in 2004, these hopes were substantially fulfilled. By-elections held under the new system featured higher support levels for winning candidates, more cooperative campaign tactics and lower levels of electoral violence than those held in the same regions just two years earlier under plurality rule. ${ }^{7}$ These patterns were repeated at the 2007 elections, which were much more peaceful than previous contests (Haley, 2008).

I have argued elsewhere that the kind of electoral engineering applied in Papua New Guinea has much wider potential application as a form of conflict management (Reilly, 2001). One reason for this is the capacity of such systems to promote a mode of politics typified as 'centripetalism' - so called 'because the explicit aim is to engineer a centripetal spin to the political system - to pull the parties towards moderate, compromising policies and to discover and reinforce the centre of a deeply divided political spectrum' (Sisk, 1995: 19). Centripetalism emphasises the need for political institutions that encourage cooperation, accommodation and integration across ethnic divides, and thus work to break down the salience of ethnicity rather than fostering its representation in parliament. Centripetal arguments maintain that the best way to mitigate the destructive effects of ethnicity in divided societies is not to simply replicate existing ethnic divisions in the legislature and other major organs of the state, but rather to de-politicise ethnic divisions by putting in place institutional incentives for politicians and their supporters to act in a cooperative, accommodatory manner towards rival groups.

In my book Democracy in Divided Societies, I defined centripetalism as a political system or strategy designed to focus competition at the moderate centre rather than the extremes by making politicians seek electoral support from groups other than their own ethnic community via three related phenomena:

1 the presentation of electoral incentives for campaigning politicians to reach out to and attract votes from a range of ethnic groups other than their own;

2 the presence of multi-ethnic arenas of bargaining, such as parliaments and executives, under which political actors from different groups come together to discuss policy issues; and

3 the development of centrist, aggregative and multiethnic political parties or coalitions of 
parties which are capable of making crossethnic appeals and presenting a complex and diverse range of policy options to the electorate (Reilly, 2001: 11).

Like the scholarly orthodoxy of consociationalism, centripetal proposals for conflict management focus on institutional structures such as political parties, electoral systems, executive governments and territorial innovations as having the most potential for political engineering. However, the specific institutional recommendations made by centripetalists in many cases run sharply counter to those of consociationalism. For example, rather than focusing on the proportional representation of ethnically defined parties, centripetalism places a premium on systems which deemphasise ethnicity and encourage crossethnic activity. This means that, in contrast to the consociational focus on the proportionality of representation for each communal segment, centripetal approaches favour a kind of aggregative majoritarianism, with more focus on the process by which different groups can be encouraged to work together than strict fairness of outcomes.

Thus, in relation to the electoral system, while consociationalists focus on the desirability of a strong congruence between votes cast and seats won in electoral results (proportionality), centripetalists advocate institutional designs that encourage opportunities for dialogue and negotiation between opposing political forces in the context of political competition. They argue that if the rules of the game are structured so as to reward cooperative political strategies with increased prospects of electoral success, candidates representing competing or even violently opposed interests can be presented with incentives to negotiate across ethnic lines for reciprocal support, and to bargain for cross-ethnic political deals and policy concessions. This is an argument consistently made by Donald Horowitz in his writings on strategies for ethnic moderation (see Horowitz, 1985: 597-600). The Papua New Guinea case provides a very clear illustration of just this kind of deal-making and conflict-management in practice, and thus represents an important (and underrecognised) case for those interested in institutional arrangements for the management of ethnic conflict.

\section{The Bougainville conflict}

While the vast majority of conflicts on the island of New Guinea are local-level contests for resources and power which have limited national or international impact, Papua New Guinea has also experienced the most violent and sustained secessionist war to have occurred anywhere in the Pacific region, on its eastern island province of North Solomons, more commonly known as Bougainville, which claimed several thousand lives (estimates vary - some sources claim that there have been 20000 casualties) and left many civilians injured, displaced and impoverished.

The conflict, which began as a dispute over the island's incorporation into the state of Papua New Guinea, has been called the most serious armed conflict in the Pacific Islands since the end of the Second World War. It centred on demands for the island's independence - a demand opposed not only by Papua New Guinea but also by many Bougainvilleans. While claims for autonomy or independence have been a feature of local politics for many decades, they gathered momentum with Papua New Guinea's independence in 1975. At that time, Bougainville's substantial contribution to the national economy was disproportionate to its small size and population, mainly because of the enormous open cut mine at Panguna in the central mountains of the main island which extracted copper, gold and silver from 1972 until the conflict caused its closure in 1989. The mine was a source of discontent not only for local landowners who felt their property rights had been infringed, but also for various Bougainvillean elites who resented the massive revenues flowing from the island to the rest of the country.

In 1988, increasing confrontation between landowners and government saw the Papua New Guinea Defence Force brought in to assist the police. Within two years, the 'Bougainville crisis' had escalated into a full-scale separatist rebellion led by a number of different rebel groups, most prominently (but not exclusively) the Bougainville Revolutionary Army. A series of increasingly violent clashes between government forces and the various pro- and antiindependence militias came to a head in 1997, when the Papua New Guinea government 
commissioned an international mercenary service, Sandline International, to attack the rebels. However, in a surprise move, the Papua New Guinean army's chief commander refused to let the Papua New Guinea Defence Force work with the mercenaries, who were ejected from the country. Prime Minister Julius Chan and two key ministers involved in engaging the mercenaries were forced to stand down. These events helped create the conditions conducive to the remarkable progress towards conflict resolution which occurred in the latter part of the 1990s. Taking advantage of that changed position at the national level, rebel forces began to make direct contact with the central government. Further developments resulted in the New Zealand government facilitating talks between the Bougainvillean leaders. These talks resulted in a cease-fire agreement, followed by the deployment of an unarmed 'Peace Monitoring Group', led by Australia, on the island, accompanied by a UN observer team.

Since then, successive agreements - notably the so-called 'Loloata Understanding' of March 2000, and the Bougainville Peace Agreement signed at Arawa in August 2001 - have successfully delivered a high degree of peace to the island. Unarmed civilian and military personnel from Australia, New Zealand, Fiji and Vanuatu were deployed as a 'Peace Monitoring Group', new autonomy arrangements have been implemented, and a range of reconciliation and reconstruction activities are also underway. In June 2005, the first elections for the Autonomous Bougainville Government were successfully held. The peace deal has also paved the way for a self-determination referendum on Bougainville's political status to be held at some unspecified time in the future, after an extended period of autonomy, although whether a referendum can actually be conducted in practice, and whether the various disputants will accept the result, remains to be seen. However, the commitment to hold and recognise the results of the referendum has been affirmed by Australia, which previously opposed any such step that could lead to independence.

\section{Conclusion}

Despite their prominence, outright campaigns for self-determination remain unusual in Papua
New Guinea. While cases such as Bougainville receive the greatest amount of attention, in many ways they are not typical of ethnic conflict in the country as a whole. While the issue of separatism is indeed important in Papua New Guinea, a greater potential problem is not secession at the periphery, but political fragmentation at the centre - an issue that receives much less attention. Such fragmentation creates distinctive problems of interest aggregation, of policy coordination, and of effective governance - problems which hamper political stability and undermine economic development. Ineffective government and economic decline can themselves generate ethnic mobilisation and group conflict and, when combined with a dysfunctional political structure, contribute to a vicious cycle of economic decay, ethnic mobilisation and conflict.

This paper has argued that in Papua New Guinea, these clear downward trends can nonetheless coexist with the maintenance of competitive democracy. This conclusion represents something of a challenge to facile presumptions about the relationship between democracy and development, which tend to assume that all good things go together, and that a functioning democracy will eventually lead to increasing economic development (or, in some versions, will eventually be overthrown and replaced by another form of regime). As the Papua New Guinea case suggests, neither of these outcomes is likely where the electoral process facilitates the victory of ethnic representatives whose primary means of servicing their electorate is to divert public goods to their own group of (usually) clan supporters. Put simply, competitive democracy will not generate public goods if the electoral process encourages social groups to use the electoral process to secure their own interests at the expense of society at large. Formal democracy can survive in the face of both ethnic fragmentation and underdevelopment, but without necessarily overcoming or generating immediate solutions to either of these afflictions. In fact, the three can coexist as long as the logic of collective action leads to divergent outcomes at the local and national levels.

The other main message of this paper is the importance of understanding the impact of ethnic demography on the incidence of ethnic 
conflict. A striking difference between Papua New Guinea and many other multiethnic states is the extent to which ethnic cleavages find political expression at the local level rather than as a contest for political hegemony at the national level. Ethnic conflict is thus typically expressed in the form of local disputes and tribal fighting rather than as a contest for control of government itself, in contrast to ethnic conflicts elsewhere. A number of observers have seen this as a potential attribute for the management of ethnic group competition when compared with post-colonial states in other regions such as Africa. For example, Kenyan scholar Ali Mazrui argued in 1970 that 'The worst troubles we have had in Africa have been in countries with very big tribes competing with each other ... . To this extent, one of Papua New Guinea's greatest assets may well be its acute ethnic fragmentation. Small ethnic groups may fight each other, but because there are so many their conflicts may remain localized. They need not shake the nation to its very foundation, as did the tensions between big ethnic giants in Nigeria, the Congo, Kenya and Uganda' (Mazrui, 1970: 54-55).

The reality of Papua New Guinea's extraordinary ethnic structure is that no group is ever likely to have sufficient support to attempt to control power at the national level, and the one ethno-regional numeric majority that could conceivably make such a claim - the Highlanders, who collectively make up close to half of Papua New Guinea's population - are probably the most fragmented and divided of all regional groups in Papua New Guinea. Similarly, attempts to mobilise ethno-regional forces in lowland Papua, where there is a relatively high degree of regional consciousness, have contributed to changes of government, but never at a level sufficient for Papuans to act as a hegemonic ethnic power. This represents a major advantage so far as the continuation of existing form of national regime is concerned, because no group 'is either subject to strong pressure to take exclusive control of the state or capable of doing so if it wishes to' (Regan, 1995: 9).

Although 'ethnic entrepreneurs' from the larger and more conspicuous ethno-regional groups make periodic attempts at mobilising support through appeals to pan-ethnic consciousness (e.g. Josephine Abaijah's Papua
Besena separatist movement in the 1970s or lambakey Okuk's similar attempts to harness a Highlander identity in the early 1980s), no group to date has been able, or has seriously attempted, to stake a claim for national domination. And, although there has been a noticeable ethno-regional quality to some governing coalitions in recent parliaments, this also appears to rotate, with governments headed by a coastal New Guinean under Michael Somare and islanders under Prime Ministers Julius Chan and Rabbie Namaliu giving way to the supremacy of Highlanders under Paias Wingti and Papuans under prime ministers Bill Skate and Mekere Morauta respectively. Somare returned to the prime ministership following the 2002 elections.

In sum, ethnic violence in Papua New Guinea remains predominantly a local-level phenomenon. At the national level, the country's multiplicity of ethno-linguistic groups means that some degree of inter-ethnic cooperation and accommodation is usually unavoidable. Thus, one reason that Papua New Guinea has been able to maintain a system of continuous democracy despite a precipitous decline in state capacity is the reality that no group has anything like the size or potential to overthrow the incumbent regime. As a result, nationallevel democracy persists in part through its own inertia, and contemporary politics is, by necessity, characterised by the products of this societal diversity - shifting alliances, cross-ethnic bargains and diverse multi-ethnic coalitions all of which have facilitated the continuity of formal democracy at the national level. ${ }^{8}$

However, because political leaders must service the needs of their tribal constituency rather than their electorate or the nation as a whole, the collective action dilemma that afflicts actors at the local level affects government policy as well. Thus, while helping to safeguard the continuity of formal democracy at the national level, Papua New Guinea's extraordinary level of ethnic diversity has also undermined the development of a national consciousness, and created serious problems of ongoing inter-ethnic competition and conflict that have undermined prospects for development and which appear to be increasing as the economy declines, the population grows and the struggle for resources, prestige and power 
become ever more intense. In terms of the 'resources conflict' theme of this volume, it must be emphasised that the biggest 'resource' in Papua New Guinea is the state itself. As such, the most sustained ethnic violence occurs in relation to access to the state, and to the benefits in terms of money, jobs, prestige and power that state resources can provide.

\section{Notes}

1 Personal communication with John Burton, Australian National University, 24 December 1996.

2 I discuss this dilemma in more detail in Reilly (2004).

3 As Claxton (2000: 268) notes, the cohesion and the utility of clan and tribal groups tend to increase as they decrease in size.

4 The term primordialism is usually associated with Geertz (1967). For a discussion of this typology in the scholarly literature, see Esman (1994: 9-16).

5 There is a considerable literature on ethnicity and ethnic identity. See Young (1976), Brass (1985), Horowitz (1985), Smith (1986), Esman (1994).

6 See 'PNG: Risk of another Bougainville', Pacific Magazine, August 2004.

7 For more on this, see Reilly (2006).

8 For more on this, see Reilly (2000).

\section{References}

Brass, P. (ed.) (1985) Ethnic groups and the state. London: Croom Helm.

Brown, P. (1989) The Simbu election, in M. Oliver (ed.), Eleksin: The 1987 national election, pp. 245-252. Port Moresby: University of Papua New Guinea.

Claxton, K. (2000) Violence, internal security, and securitystakeholders in Papua New Guinea, in S. Dinnen and A. Ley (eds.), Reflections on violence in Melanesia, pp. 263-276. Canberra: Hawkins Press and Asia Pacific Press.

Clifford, W., L. Morauta and B. Stuart (1984) Law and order in Papua New Guinea. Port Moresby: Institute of National Affairs and Institute of Applied Social and Economic Research.

de Lepervanche, M. (1973) Social structure, in P. Ryan (ed.), The encyclopedia of Papua and New Guinea, pp. 1065-1079. Clayton: Melbourne University Press in Association with the University of Papua New Guinea.

Dinnen, S. (1996) Violence, security and the 1992 election, in Y. Saffu (ed.), The 1992 Papua New Guinea election: Change and continuity in electoral politics, pp. 91-98. Canberra: Department of Political and Social Change, Research School of Pacific and Asian Studies, Australian National University.

Dorney, S. (1990) Papua New Guinea: People, politics and history since 1975. Sydney: Random House.

Esman, M. (1994) Ethnic politics. Ithaca, New York: Cornell University Press.
Ferguson, R. and N. Whitehead (1992) War in the tribal zone: Expanding states and indigenous warfare. Santa Fe: School of American Research Press.

Filer, C. (2000) Compensation, rent and power in Papua New Guinea, in S. Toft (ed.), Compensation for resource development in Papua New Guinea, pp. 156-190. Port Moresby and Canberra: Law Reform Commission of Papua New Guinea and Australian National University.

Geertz, C. (1967) Old societies and new states: The quest for modernity in Asia and Africa. New York: Free Press.

Goldman, L. (2003) 'Hoo-Ha in Huli': Considerations on commotion and community in the Southern Highlands Province of Papua New Guinea. Paper presented to workshop on 'Conflict in the Southern Highlands Province, Papua New Guinea', Australian National University, Canberra, 26-27 May 2003.

Haley, N. (2008) Election 2007 domestic observation: Key findings and overall assessment. Paper presented to the Papua New Guinea Election 2007 Workshop, Australian National University, Canberra, 5 February 2008.

Hogbin, I. (1973) Anthropological definitions, in P. Ryan (ed.), The encyclopedia of Papua and New Guinea, pp. 23-25. Clayton: Melbourne University Press in Association with the University of Papua New Guinea.

Horowitz, D. (1985) Ethnic groups in conflict. Berkeley, California: University of California Press.

Howard, M. (1989) Ethnicity and the state in the Pacific, in M. Howard (ed.), Ethnicity and nation building in the Pacific, pp. 1-49. Tokyo: United Nations University Press.

Levine, S. (1997) Culture and conflict in Fiji, Papua New Guinea, Vanuatu, and the Federated States of Micronesia, in M.E. Brown and S. Ganguly (eds.), Government policies and ethnic relations in the Asia-Pacific, pp. 457-508. Cambridge and London: MIT Press.

May, R.J. (2003a) Harmonizing linguistic diversity in Papua New Guinea, in M.E. Brown and S. Ganguly (eds.), Fighting words: Language policy and ethnic relations in Asia, pp. 291-317. Cambridge, Massachusetts: MIT Press.

May, R.J. (2003b) Turbulence and reform in Papua New Guinea, Journal of Democracy 14(1): 154-165.

Mazrui, A. (1970) An African's New Guinea, New Guinea 5(3): 54-55.

Parker, R.S. and E.P. Wolfers (1971) The context of political change, in A.L. Epstein, R.S. Parker and M. Reay (eds.), The politics of dependence: Papua New Guinea 1968. Canberra: Australian National University Press.

Premdas, R. (1989) Ethnicity and nation-building: The Papua New Guinea case, in M. Howard (ed.), Ethnicity and nation building in the Pacific, pp. 244-258. Tokyo: United Nations University Press.

Reay, M. (1982) Lawlessness in the Papua New Guinea highlands, in R.J. May and H. Nelson (eds.), Melanesia: beyond diversity, pp. 630-636. Canberra: Research School of Pacific Studies, Australian National University.

Regan, A. (1995) Limiting state action: Comparative perspectives on constitutionalism, participation and civil society in Papua New Guinea. Paper presented to the 1995 Waigani Seminar, Port Moresby. 
Reilly, B. (2000) Democracy, ethnic fragmentation, and internal conflict: Confused theories, faulty data, and the 'crucial case' of Papua New Guinea, International Security 25(3): 162-185.

Reilly, B. (2001) Democracy in divided societies: Electoral engineering for conflict management. Cambridge: Cambridge University Press.

Reilly, B. (2002) Back to the future? The political consequences of electoral reform in Papua New Guinea, Journal of Pacific History 37(2): 239-253.

Reilly, B. (2004) Ethnicity, democracy and development in Papua New Guinea, Pacific Economic Bulletin of the 19(1): 46-54.

Reilly, B. (2006) Political reform in Papua New Guinea: Testing the evidence, Pacific Economic Bulletin of the 21(1): 187-194.

Sisk, T. (1995) Democratization in South Africa: The elusive social contract. Princeton, New Jersey: Princeton University Press.
Smith, A. (1986) The ethnic origin of nations. Oxford: Blackwell.

Souter, G. (1963) New Guinea: The last unknown. Sydney: Angus and Robertson.

Standish, B. (1996) Elections in Simbu: Towards gunpoint democracy? in Y. Saffu (ed.), The 1992 Papua New Guinea election: Change and continuity in electoral politics. Canberra: Department of Political and Social Change, Research School of Pacific and Asian Studies, Australian National University.

Strathern, A. (1993) Violence and political change in Papua New Guinea, Pacific Studies 16(4): 41-60.

Tollison, R. (1997) Rent seeking, in D. Mueller (ed.), Perspectives on public choice: A handbook, pp. 506-525. New York: Cambridge University Press.

Young, C. (1976) The politics of cultural pluralism. Madison, Wisconsin: University of Wisconsin Press. 